\title{
Probucol inhibits hydrogen peroxide to induce apoptosis of vascular smooth muscle cells
}

\author{
LIN SHENG $^{1}$, BO JIAO ${ }^{2}$, LIJUAN SHAO ${ }^{2}$, SHAOJIE BI $^{1}$, CHAO CHENG $^{1}$, JINGBO ZHANG $^{1}$ and YIHAO JIANG ${ }^{3}$ \\ ${ }^{1}$ Department of Cardiology, Second Hospital of Shandong University, Jinan, Shandong 250033; \\ ${ }^{2}$ Department of Pharmacology, College of Pharmacy, Shandong University, Jinan, Shandong 250012; \\ ${ }^{3}$ College of Environmental and Chemical Engineering, Nanchang University, Nanchang, Jiangxi 330031, P.R. China
}

Received June 28, 2012; Accepted October 31, 2012

DOI: $10.3892 / \mathrm{mmr} .2013 .1299$

\begin{abstract}
The aim of this study was to investigate the effect of the antioxidant probucol on hydrogen peroxide $\left(\mathrm{H}_{2} \mathrm{O}_{2}\right)$ induced vascular smooth muscle cell (VSMC) apoptosis. $\mathrm{H}_{2} \mathrm{O}_{2}(1 \mathrm{mmol} / \mathrm{l})$ was used as the VSMC apoptosis-inducing agent, and 100, 10 and $1 \mu \mathrm{mol} / 1$ probucol concentrations were incubated with cells for $6 \mathrm{~h}$. The cell apoptosis was observed using Annexin V-FITC, TUNEL and Hoechst 33258 staining methods. $\mathrm{H}_{2} \mathrm{O}_{2}$ promoted VSMC apoptosis, ASK-1 protein expression increased and Trx-1 protein expression decreased. Probucol reduced $\mathrm{H}_{2} \mathrm{O}_{2}$-induced apoptosis in a dose-dependent manner; while ASK-1 protein expression decreased, Trx-1 protein expression increased. Probucol is capable of antagonizing the $\mathrm{H}_{2} \mathrm{O}_{2}$-induced apoptosis in VSMCs, which may be related to the decrease in ASK-1 protein expression and the increase in Trx-1 protein expression.
\end{abstract}

\section{Introduction}

Atherosclerosis (AS) plaque cell apoptosis is the main factor leading to plaque instability (1-3). Cell apoptosis occurs in various periods of AS damage. Apoptotic cells in the plaque are mainly vascular smooth muscle cells (VSMCs) and macrophages. Excessive VSMC proliferation and apoptosis constitute the main pathological basis of AS plaque formation, which has a significant impact on the development and outcome of AS $(3,4)$. AS plaque formation depends on the relative balance of apoptosis and proliferation of VSMCs. Cell proliferation is dominant in the early period of AS. With progression of AS, particularly in the late stage, VSMC apoptosis directly affects the arterial shape and structure, and increases the plaque instability. This is the major factor causing clinical manifesta-

Correspondence to: Dr Yihao Jiang, College of Environmental and Chemical Engineering, Nanchang University, 999 Yue Fu Avenue, Honggutan New Zone, Nanchang, Jiangxi 330031, P.R. China E-mail: yihaojiangmed@126.com

Key words: probucol, vascular smooth muscle cells, hydrogen peroxide, apoptosis signal, regulated protein kinase, thioredoxin tions (5). Thus, preventing apoptosis of VSMCs in late-stage AS would have a positive impact in preventing the occurrence of serious clinical AS complications.

As the knowledge of the importance of oxidative stress and oxidized low density lipoprotein in the pathogenesis of AS has increased, experimental reports on probucol inhibition of AS progression, promotion of regression of the AS plaque, and prevention of restenosis following interventional therapy have been increasing (6-8). The correlation between probucol and inflammatory mediators, endothelial function, cytokines, antioxidant enzymes, particularly the correlation between intracellular signaling proteins and transcription factor activity on VSMC proliferation and apoptosis, and the role in the AS pathophysiology, has become a hot topic of research in recent years $(7,9,10)$. Previous studies confirmed that by maintaining intracellular redox balance, probucol reduced intracellular GSH consumption and inhibited $\mathrm{H}_{2} \mathrm{O}_{2}$ induced apoptosis in VSMCs (11). In the process of apoptosis, Trx-1 and ASK-1 associated with MAPK pathways also play an important role. Whether the anti-apoptotic effects of probucol are related to these factors has not been reported. In this study, $\mathrm{H}_{2} \mathrm{O}_{2}$ was used as an apoptosis-inducing agent, and we observed the effect of probucol on VSMC apoptosis and Trx-1 and ASK-1 expression, and explored its anti-apoptotic mechanism.

\section{Materials and methods}

Animals. Healthy Wistar rats, male, clean and weighing $171 \pm 18 \mathrm{~g}$, were provided by the Experimental Animal Center of Shandong University. The study was approved by the College of Environmental and Chemical Engineering, Nanchang University, Nanchang, Jiangxi, P.R. China.

VSMC culture. VSMCs were cultured using the tissue attached method. Rat thoracic aorta was obtained, the vascular adventitia was stripped, the endometrium was removed, cut into $1 \times 1 \mathrm{~mm}$ tissue slices and attached to the culture bottle, cultured at $37^{\circ} \mathrm{C}$ in $5 \% \mathrm{CO}_{2}$ conditions containing $20 \%$ fetal calf serum DMEM medium, and the medium was changed once every 3-5 days. When the cells grew to be $60-80 \%$ confluent, $0.25 \%$ trypsin was added for digestion and cells were passaged at 4-6 days. Cells were spindle-shaped, and the typical 'peak-valley'-like 
structure appeared when they grew into a dense layer. VSMCs of passage 3-8 were used in this experiment.

Flow cytometry. VSMCs were digested with $0.25 \%$ trypsin, adjusting the cell concentration to $2 \times 10^{7}$ cells/1 density and seeded in 96-well culture plates. The cells were divided into a control group, a model group $\left(1 \mathrm{mmol} / \mathrm{H}_{2} \mathrm{O}_{2}\right.$,), and probucol $1,10,100 \mu \mathrm{mol} / 1$ groups. After $24 \mathrm{~h}$ of culture at $37^{\circ} \mathrm{C}$ in a $5 \%$ $\mathrm{CO}_{2}$ incubator, $\mathrm{H}_{2} \mathrm{O}_{2}$ and probucol were added and the cells were cultured for $6 \mathrm{~h}$. The medium was then discarded, cells were washed with PBS and dispersed into single cells following digestion with $0.25 \%$ trypsin protease. The cell suspension $\left(0.5-1 \times 10^{6} / \mathrm{ml}\right)$ was washed twice with PBS, centrifuged at $2000 \mathrm{rpm} / \mathrm{min}$ for $5 \mathrm{~min}$, the supernatant was discarded and $100 \mu \mathrm{l}$ binding buffer and $10 \mu \mathrm{l}$ FITC-labeled Annexin V (20 $\mu \mathrm{g} / \mathrm{ml})$ were added. The samples were kept in the dark at room temperature for $30 \mathrm{~min}$, then $5 \mu \mathrm{l} \mathrm{PI}(50 \mu \mathrm{g} / \mathrm{ml})$ was added, the samples were reacted in the dark for $5 \mathrm{~min}, 400 \mu \mathrm{l}$ binding buffer was added, and the cells were immediately detected by flow cytometry using FACScan. Samples without Annexin V-FITC and PI were used as the negative control. Cell apoptosis was analyzed using WinMDI29 image processing software. The effects of different concentrations of probucol treatment on the apoptosis rate of VSMCs were observed.

TUNEL staining. The cell groups mentioned previously were cultured in 6-well plates (built-in cover glass). The coverslips inoculated with cells were taken and stained according to the TUNEL labeling staining kit instructions and observed under the microscope. The nuclei that appeared brown were positive. Four slides were observed, each at x200 magnification, in order to calculate the apoptosis index (AI). AI represented the percentage of the number of positive cells and the total cell number in five views selected from each slide.

Hoechst 33258 staining. The cultured cells were taken, washed with PBS and fixed for $10 \mathrm{~min}$. Cells were washed with PBS, and stained with Hoechst 33258 dye at room temperature for $10 \mathrm{~min}$. After washing with PBS, excess liquid was absorbed, cells were mounted under a fluorescence microscope, and the morphological changes of the cells were observed.

Western blot analysis. After the cells were collected and washed three times with iced PBS, lysed by adding an appropriate amount of lysate in ice bath conditions and centrifuged at $12000 \mathrm{rpm}$ for $15 \mathrm{~min}$, the supernatant was carefully drawn, and the protein concentration was determined using the BCA method. Protein samples $(40 \mu \mathrm{g})$ were taken, ASK-1 proteins were separately run on $10 \%$ SDS-PAGE gels, and Trx-1 on $15 \%$ SDS-PAGE gels (laminated plastic $80 \mathrm{mV}$, gel $120 \mathrm{mV}$ ), then electrophoretically transferred $(150 \mathrm{~mA}, 1.5 \mathrm{~h})$ to a PVDF membrane, blocked using 5\% non-fat dry milk for $1 \mathrm{~h}$, and incubated with rabbit anti-ASK-1 (1:100) and Trx-1 (1:100) polyclonal antibodies overnight at $4{ }^{\circ} \mathrm{C}$. After washing with TBST three times, 1:1000 concentrations of second antibody were added for $1 \mathrm{~h}$. After washing with TBST three times, the membranes were evenly coated with the same amount of chemiluminescence A and B solution and underwent electrochemiluminescence immunoassay (ECL) for $5 \mathrm{~min}$. A GIS image processing system was used for analysis.
Table I. Effect of $\mathrm{H}_{2} \mathrm{O}_{2}$ on VSMC apoptosis rate (mean \pm SD, $\mathrm{n}=4)$.

\begin{tabular}{lccc}
\hline Group & $\begin{array}{c}\text { Concentration } \\
(\mu \mathrm{mol} / \mathrm{l})\end{array}$ & $\begin{array}{c}\text { Living cell } \\
\text { rate }(\%)\end{array}$ & $\begin{array}{c}\text { Apoptosis } \\
\text { rate }(\%)\end{array}$ \\
\hline Control & & $95.03 \pm 5.27$ & $1.73 \pm 0.85$ \\
$\mathrm{H}_{2} \mathrm{O}_{2}$ & 100 & $94.52 \pm 6.43$ & $2.35 \pm 0.81$ \\
& 250 & $93.13 \pm 8.82$ & $3.10 \pm 1.26$ \\
& 500 & $80.49 \pm 3.16$ & $7.39 \pm 1.04$ \\
& 1000 & $60.31 \pm 4.60$ & $28.87 \pm 2.31^{\mathrm{a}}$ \\
\hline
\end{tabular}

All values are presented as the means \pm SD of 3 experiments. ${ }^{\mathrm{a}} \mathrm{P}<0.01$ compared with control. $\mathrm{H}_{2} \mathrm{O}_{2}$, hydrogen peroxide; VSMC, vascular smooth muscle cell.

Table II. Effect of different concentrations of probucol on $\mathrm{H}_{2} \mathrm{O}_{2}$-induced VSMC apoptosis (Hoechst 33258 staining) (mean $\pm \mathrm{SD}, \mathrm{n}=4$ ).

\begin{tabular}{lccc}
\hline Group & $\begin{array}{c}\text { Concentration } \\
(\mu \mathrm{mol} / 1)\end{array}$ & $\begin{array}{c}\text { Living cell } \\
\text { rate }(\%)\end{array}$ & $\begin{array}{c}\text { Apoptosis } \\
\text { rate }(\%)\end{array}$ \\
\hline Control & & $97.86 \pm 5.27$ & $1.46 \pm 0.82$ \\
$\mathrm{H}_{2} \mathrm{O}_{2}$ & 1000 & $68.54 \pm 1.43$ & $29.57 \pm 5.81^{\mathrm{a}}$ \\
Probucol & 100 & $92.18 \pm 7.82$ & $3.50 \pm 1.54^{\mathrm{b}}$ \\
& 10 & $85.17 \pm 6.92$ & $12.36 \pm 4.10^{\mathrm{c}}$ \\
& 1 & $79.68 \pm 4.50$ & $17.96 \pm 2.81$
\end{tabular}

All values are presented as the means $\pm \mathrm{SD}$ of 3 experiments. ${ }^{\mathrm{a}} \mathrm{P}<0.01$ compared with control; ${ }^{b} \mathrm{P}<0.05$ compared with $\mathrm{H}_{2} \mathrm{O}_{2}$; ${ }^{\mathrm{c}} \mathrm{P}<0.01 \mathrm{com}$ pared with $\mathrm{H}_{2} \mathrm{O}_{2} \cdot \mathrm{H}_{2} \mathrm{O}_{2}$, hydrogen peroxide; VSMC, vascular smooth muscle cell.

Statistical analysis. SPSS 15 statistical software was used for analysis, and data were shown with the means \pm SD. Sample means were compared using analysis of variance and the LSD pairwise comparison method.

\section{Results}

VSMC apoptosis. As shown in Table I, H2O2 had marked effects on the VSMC apoptosis rate. Flow cytometry analysis showed that VSMC apoptosis was significantly increased by $23.9 \pm 5.8 \%$ after cells were treated with $\mathrm{H}_{2} \mathrm{O}_{2}$ for $6 \mathrm{~h}$. Compared with the $\mathrm{H}_{2} \mathrm{O}_{2}$ group, the probucol group significantly inhibited $\mathrm{H}_{2} \mathrm{O}_{2}$-induced apoptosis, and the apoptotic rates were $3.8 \pm 2.8 \%$ in the $100 \mu \mathrm{mol} / 1$ group $(\mathrm{P}<0.01), 11.3 \pm 4.1 \%$ in the $10 \mu \mathrm{mol} / 1$ group $(\mathrm{P}<0.05)$ and $16.8 \pm 4.5 \%$ in the $1 \mu \mathrm{mol} / 1$, showing a concentration-dependent effect (Figs. 1 and 2). Hoechst 33258 staining showed that nuclear condensation occurred in the $\mathrm{H}_{2} \mathrm{O}_{2}$ treatment group. A compact fluorescent stain was observed in the nucleus and cytoplasm, with a deep and bright color. Hoechst 33258 staining showed that nuclear condensation occurred in the $\mathrm{H}_{2} \mathrm{O}_{2}$ treatment group. A compact fluorescent stain was observed in the nucleus and 


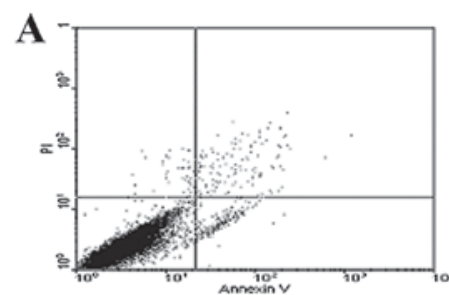

Total Events 12218 Gated Events 12218 $100.00 \%$

System Log Parameter Means: Geometric

L1-H(Log)vs FL2-H(Log)

Quadrant x,y. 340,308

Quad X-Mean Y-Mean Events\%Total \%Gated

IUL 109918

$\begin{array}{llllll}\text { UR } & 813 & 663 & 0.47 & 0.47\end{array}$

$\begin{array}{llllllllll} & 32 & 6.3 & 391 & 3.20 & 3.20\end{array}$

$\begin{array}{rrrrrr}3 \mathrm{LL} & 3.2 & 2.2 & 11554 & 94.57 & 94.57 \\ 4 \mathrm{LR} & 470 & 5.9 & 216 & 1.77 & 1.77\end{array}$

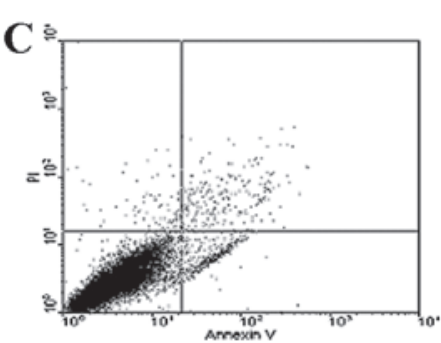

Total Events 13234 Gated Events 13234 $100.00 \%$

System Log Parameter Means: Geometric Quad Stats

FL1-H(Log) vs FL2-H(Log)

Quadrant x,y. 340,308

Quad X-Mean Y-Mean Events \%Total \%Gated

$\begin{array}{llllll}1 \text { UL } & 3.4 & 93.2 & 108 & 0.82 & 0.82\end{array}$

$\begin{array}{llllll}2 \text { UR } & 1006 & 74.5 & 404 & 3.05 & 3.05\end{array}$

$\begin{array}{rrrrrr}3 L & 3.8 & 2.8 & 12320 & 93.09 & 93.09 \\ 4 \mathrm{LR} & 55.7 & 6.5 & \mathbf{4 0 2} & 3.04 & 3.04\end{array}$

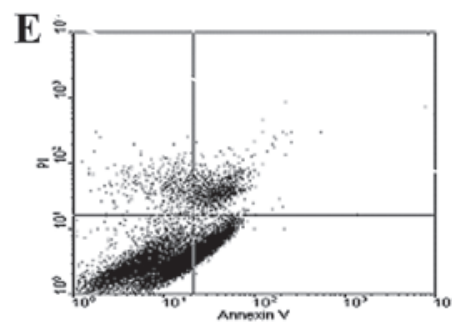

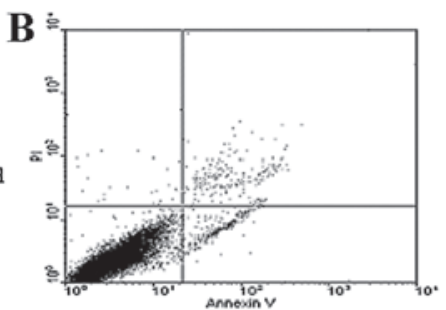

Total Events 12008 Gated Events 12008 $100.00 \%$ System: Log Parameter Means: Geometric Quad Stats FL1-H(Log) vs FL2-H(Log) Quachant xy: 340,308

Quad XMean Y-Mean Everts \%Total \%Gated

$\begin{array}{llllll}1 \text { IUL } & 5.3 & 239.3 & 44 & 037 & 0.37\end{array}$

$\begin{array}{llllll}2 \mathrm{UR} & 128.4 & 88.4 & 256 & 2.13 & 2.13\end{array}$ $\begin{array}{lrrrrr}3 \mathrm{LL} & 3.5 & 2.3 & 11424 & 95.14 & 95.14 \\ \text { 4LR } & 73.2 & 6.4 & 284 & 237 & 2.37\end{array}$

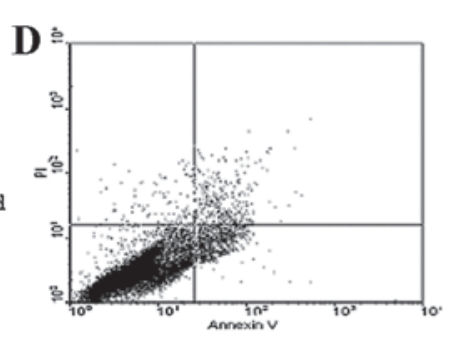

Total Events 14067 Gated Events $14967 \quad 100.00 \%$ System: Log Parameter Means: Geometric

FL1-H(Log) vs FL2-H(Log)

Quadrant xy: 340,308

Quad X-Mean Y-Mean Everts \%Total \%Gated

$\begin{array}{llllll}1 \mathrm{UL} & 10.2 & 48.0 & 1233 & 826 & 8.25\end{array}$

$\begin{array}{llllll}2 \mathrm{UR} & 41.7 & 510 & 572 & 3.82 & 3.82\end{array}$ $\begin{array}{lccccc}3 \mathrm{LL} & 47 & 2.6 & 12060 & 9.58 & 9.58 \\ 4 \mathrm{LR} & 33.4 & 6.0 & 1099 & 7.34 & 7.34\end{array}$

Figure 1. Effects of different concentrations of $\mathrm{H}_{2} \mathrm{O}_{2}$ on VSMC apoptosis. Cells were cultured with or without $\mathrm{H}_{2} \mathrm{O}_{2}\left(100-1000 \mu\right.$ mol $\left.\cdot^{-1}\right)$. The cell apoptosis rate was evaluated by flow cytometry at the indicated time. All values are presented as the means $\pm \mathrm{SD}$ of 4 experiments. $(\mathrm{A}) \mathrm{Control}$; $(\mathrm{B}) \mathrm{H}_{2} \mathrm{O}_{2} 100 \mu$ mol/1; $(\mathrm{C})$ $\mathrm{H}_{2} \mathrm{O}_{2} 250 \mu \mathrm{mol} / 1$; (D) $\mathrm{H}_{2} \mathrm{O}_{2} 500 \mu \mathrm{mol} / \mathrm{l}$; (E) $\mathrm{H}_{2} \mathrm{O}_{2} 1000 \mu \mathrm{mol} / 1 . \mathrm{H}_{2} \mathrm{O}_{2}$, hydrogen peroxide; VSMC, vascular smooth muscle cell.

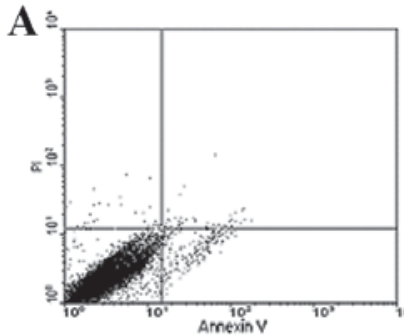

Total Events 1588 ? Gated Events $15887 \quad 100.00 \%$ System:Log Parameter Means: Geometric

FL1-H(Log)vs FL2-H(Log)

Quadrant x,y. 328,28

Quad X-Mean Y-Mean Events \%Total \%Gated

$\begin{array}{lrllll}1 \text { UL } & 5.7 & 19.8 & 33 & 0.21 & 0.21\end{array}$

$\begin{array}{cccccc}2 \text { UR } & 58.3 & 17.3 & 37 & 0.23 & 0.23 \\ 3 U & 2.2 & 1.8 & 15618 & 98.33 & 98.33\end{array}$

$\begin{array}{lrlccc}\text { 4LR } & 41.9 & 6.6 & 213 & 1.34 & 1.34\end{array}$

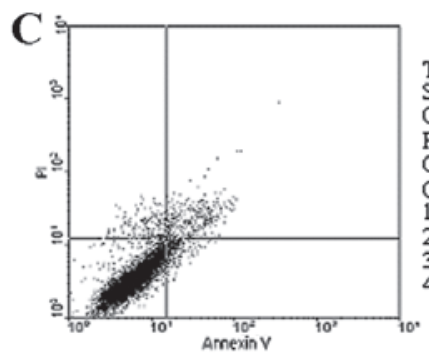

Total Events 11251 Gated Events $11251 \quad 10000 \%$ System: Log Parameter Means: Geometric Quad Stats

L1-H(Log) vs FL2-H(Log)

Quadrant x,y. 308,276

and X-Mean Y-Mean Events\%Total \%Gated

UL $\begin{array}{lllll}10.2 & 34.4 & 204 & 1.81 & 1.81\end{array}$

$\begin{array}{llllll}2 \text { UR } & 30.8 & 35.9 & 362 & 3.22 & 3.22\end{array}$

$\begin{array}{lrrrrr}3 \mathrm{~L} & 6.4 & 3.3 & 10258 & 91.18 & 91.18\end{array}$
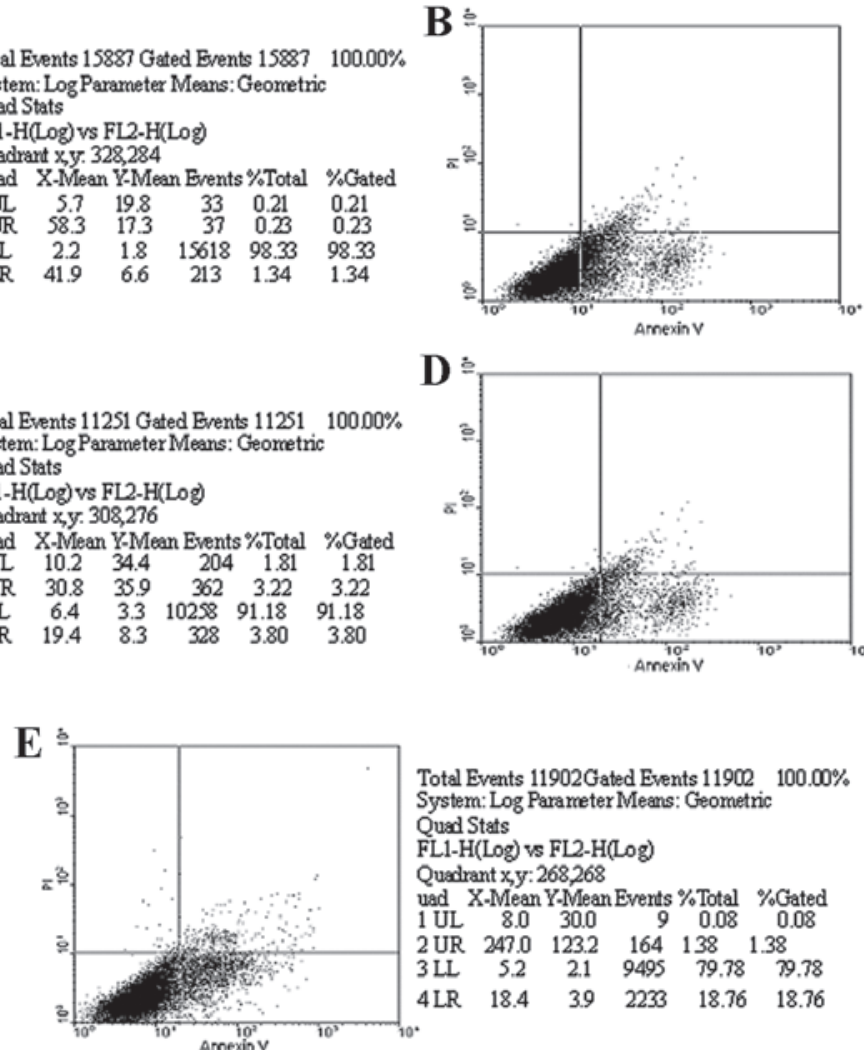

Total Everts 11968 Gated Events $11968 \quad 100.00 \%$

System: Log Parameter Mears: Geometric

Quad Stats

FL1-H(Log) vs FL2-H(Log)

Quachant x,y: 258,258

Quad XMean Y-Mean Events \%Total \%Gated

$\begin{array}{rrrrrr}1 \text { UL } & 4.9 & 13.1 & 2 & 0.02 & 0.02 \\ \text { 2UR } & 41.5 & 163 & 221 & 185 & 1.85\end{array}$

$\begin{array}{llllll}2 \text { UR } & 41.5 & 163 & 221 & 1.85 & 1.85\end{array}$

$\begin{array}{lrllll}3 L L & 5.9 & 22 & 8165 & 68.22 & 6822 \\ 4 L R & 21.9 & 39 & 3580 & 29.91 & 29.91\end{array}$

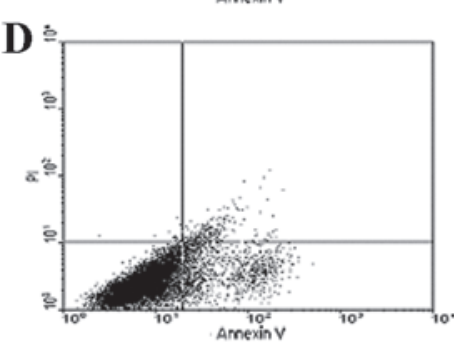

Total Events 11968 Gated Events $11968 \quad 100.00 \%$ System: Log ParameterMears: Geometric Quad Stats FL1-H(Log) vs FL2H(Log)

Quadmt xy: 332,206

Quad X-Mean Y-Mean Events \%Total \%Gated

$\begin{array}{llllll}1 \text { UL } & 17.2 & 17.3 & 10 & 0.83 & 0.83\end{array}$

$\begin{array}{llllll}2 \text { UR } & 51.5 & 21.3 & 16 & 1.29 & 129\end{array}$

$\begin{array}{llllll}4 & 7.1 & 2.4 & 10425 & 87.11 & 87.11\end{array}$

Figure 2. Effect of $\mathrm{H}_{2} \mathrm{O}_{2}$ on the VSMC apoptosis rate. Cells were cultured with $\mathrm{H}_{2} \mathrm{O}_{2} 1000 \mu \mathrm{mol} \cdot \mathrm{l}^{-1}$ and different concentrations of 100 , 10 and $1 \mu$ mol-1 probucol for $6 \mathrm{~h}$. The cell apoptosis rate was evaluated using flow cytometry at the indicated time. All values are presented as the means $\pm \mathrm{SD}$ of 4 experiments (A) Control; (B) $\mathrm{H}_{2} \mathrm{O}_{2} 1000 \mu \mathrm{mol} / 1$; (C) Probucol $100 \mu \mathrm{mol} / 1+\mathrm{H}_{2} \mathrm{O}_{2} 1000 \mu \mathrm{mol} / \mathrm{l}$; (D) Probucol $10 \mu \mathrm{mol} / 1+\mathrm{H}_{2} \mathrm{O}_{2} 1000 \mu \mathrm{mol} / 1$; (E) Probucol $1 \mu \mathrm{mol} / 1+\mathrm{H}_{2} \mathrm{O}_{2}$ $1000 \mu \mathrm{mol} / 1 . \mathrm{H}_{2} \mathrm{O}_{2}$, hydrogen peroxide; VSMC, vascular smooth muscle cell. 

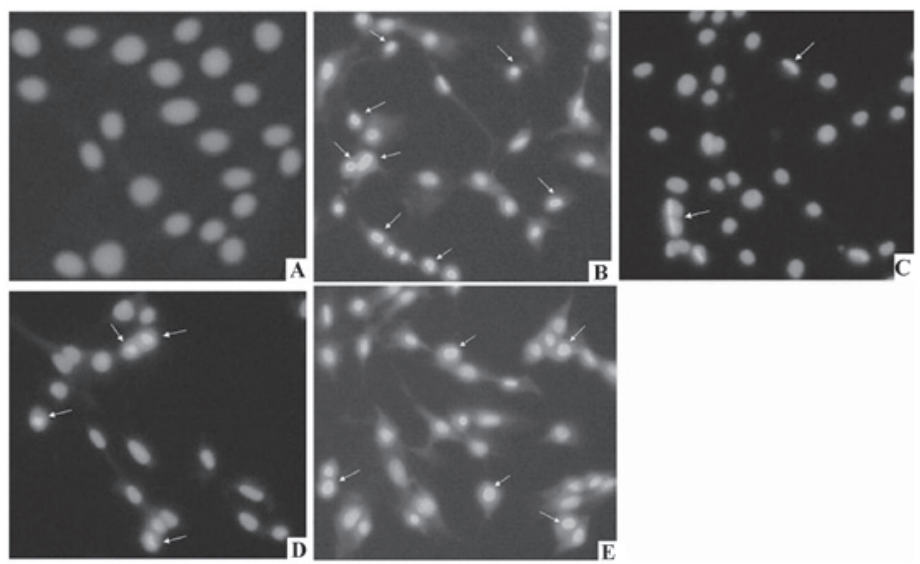

Figure 3. Effect of probucol on $\mathrm{H}_{2} \mathrm{O}_{2}$-induced morphology of VSMCs by nuclear staining with Hoechst 33258 (x200). Cells grown on glass slips were treated with $1000 \mu \mathrm{mol} \cdot \mathrm{l}^{-1} \mathrm{H}_{2} \mathrm{O}_{2}$ and different concentrations of 100,10 and $1 \mu \mathrm{mol} \cdot \mathrm{l}^{-1}$ probucol for $6 \mathrm{~h}$ and the Hoechst 33258 staining was performed. (A) Control; B) $1000 \mu \mathrm{mol} / 1 \mathrm{H}_{2} \mathrm{O}_{2}$; (C) $100 \mu \mathrm{mol} \cdot l^{-1}$; (D) $10 \mu \mathrm{mol} \cdot l^{-1}$; and (E) $1 \mu \mathrm{mol} \cdot l^{-1}$ probucol, respectively (magnification, $\mathrm{x} 200$ ). $\mathrm{H}_{2} \mathrm{O}_{2}$, hydrogen peroxide; VSMCs, vascular smooth muscle cells.

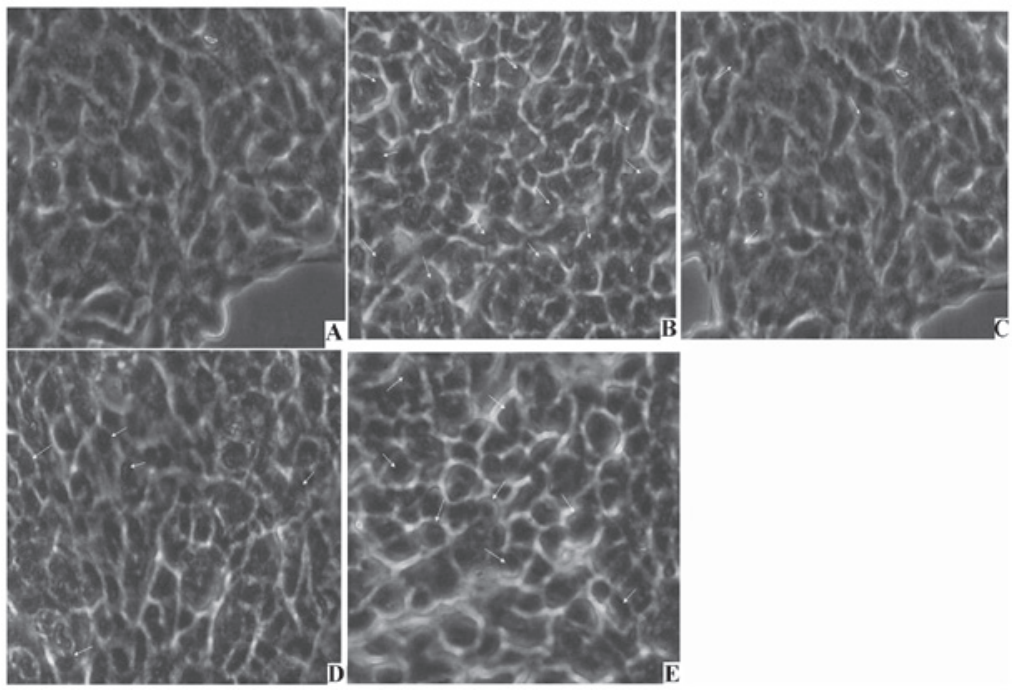

Figure 4. Effect of probucol on DNA of $\mathrm{H}_{2} \mathrm{O}_{2}$-induced VSMCs by nuclear staining with TUNEL. Cells grown on glass slips were treated with $1000 \mu$ mol. $\mathrm{l}^{-1}$ $\mathrm{H}_{2} \mathrm{O}_{2}$ and different concentrations of 100,10 and $1 \mu \mathrm{mol} \cdot \cdot^{-1}$ probucol for $6 \mathrm{~h}$ and TUNEL staining was performed. (A) Control; (B) $1000 \mu \mathrm{mol} \cdot \cdot^{-1} \mathrm{H}_{2} \mathrm{O}_{2}$; (C) $100 \mu \mathrm{mol} \cdot \mathrm{l}^{-1}$; (D) $10 \mu \mathrm{mol} \cdot l^{-1}$; and (E) $1 \mu \mathrm{mol} \cdot l^{-1}$ probucol, respectively (magnification, $\mathrm{x} 400$ ). $\mathrm{H}_{2} \mathrm{O}_{2}$, hydrogen peroxide; VSMCs, vascular smooth muscle cells.

cytoplasm (Fig. 3). Compared to control (1.46 $\pm 0.82 \%)$, VSMC apoptosis rates for the $\mathrm{H}_{2} \mathrm{O}_{2}$ group, and the $100,10,1 \mu \mathrm{mol} / 1$ probucol groups were $29.57 \pm 5.81,3.50 \pm 1.54,12.36 \pm 4.10$ and $17.96 \pm 2.81 \%$, respectively (Table II). The TUNEL assay revealed that apoptotic nuclei were brown in color, had nuclear condensation, the chromatin condensed into a cluster, and showed a strong positive change (Fig. 4, Table III). The AI in the control group was $3.22 \pm 1.12 \%$, in the $\mathrm{H}_{2} \mathrm{O}_{2}$ group it was $28.28 \pm 5.24 \%$, in the $100 \mu \mathrm{mol} / 1$ probucol group it was $4.58 \pm 1.27 \%$ ( $\mathrm{P}<0.01$ compared with the $\mathrm{H}_{2} \mathrm{O}_{2}$ group), in the $10 \mu \mathrm{mol} / 1$ it was $11.38 \pm 2.46 \%(\mathrm{P}<0.05$ compared with the $\mathrm{H}_{2} \mathrm{O}_{2}$ group), and in the $1 \mu \mathrm{mol} / 1$ group it was $18.33 \pm 3.24 \%$.

ASK-1 and Trx-1 protein expression. After VSMCs were treated with $1 \mathrm{mmol} / 1 \mathrm{H}_{2} \mathrm{O}_{2}$ the ASK-1 protein expression was significantly increased and Trx-1 protein expression decreased, compared with the control group. Probucol treat- ment is capable of reducing the ASK-1 protein expression and increasing Trx-1 expression (Fig. 5, Table IV).

\section{Discussion}

Oxidative stress is considered to be a major factor that causes VSMC damage. Reactive oxygen species (ROS) play an important role in mediating the process of vascular wall apoptosis $(12,13)$. As they constitute the vessel wall structure and are the major cellular components in the maintenance of vascular tone, VSMCs are important in AS. Under many pathological conditions, both oxidized low-density lipoprotein (ox-LDL)induced VSMC apoptosis and VSMC proliferation stimulated by high glucose, ROS are important mediating factors (14-16). ROS are capable of altering the intracellular redox balance, activating the redox-sensitive signaling protein kinases and transcription factors, and inducing apoptosis and proliferation 
Table III. Effect of different concentrations of probucol on $\mathrm{H}_{2} \mathrm{O}_{2}$-induced VSMC apoptosis (TUNEL method) (mean $\pm \mathrm{SD}, \mathrm{n}=4$ ).

\begin{tabular}{lcc}
\hline & $\begin{array}{c}\text { Concentration } \\
(\mu \mathrm{mol} / \mathrm{l})\end{array}$ & $\begin{array}{c}\text { Apoptotic index } \\
(\%)\end{array}$ \\
\hline Control & & $3.22 \pm 1.12$ \\
$\mathrm{H}_{2} \mathrm{O}_{2}$ & 1000 & $28.28 \pm 5.24^{\mathrm{a}}$ \\
Probucol & 100 & $4.58 \pm 1.27^{\mathrm{c}}$ \\
& 10 & $11.38 \pm 2.46^{\mathrm{b}}$ \\
& 1 & $18.33 \pm 3.24$ \\
\hline
\end{tabular}

${ }^{\mathrm{a}} \mathrm{P}<0.01$ compared with control, ${ }^{\mathrm{b}} \mathrm{P}<0.05,{ }^{\mathrm{c}} \mathrm{P}<0.01$ compared with $\mathrm{H}_{2} \mathrm{O}_{2} \cdot \mathrm{H}_{2} \mathrm{O}_{2}$, hydrogen peroxide; VSMC, vascular smooth muscle cell.

Table IV. Effects of different concentrations of probucol on the expression of ASK-1 and Trx-1 in VSMCs stimulated by $\mathrm{H}_{2} \mathrm{O}_{2}$ (mean $\pm \mathrm{SD}, \mathrm{n}=4$ ).

\begin{tabular}{lcc}
\hline & ASK-1 & Trx-1 \\
\hline Control & $0.80 \pm 0.04$ & $2.52 \pm 0.06$ \\
$\mathrm{H}_{2} \mathrm{O}_{2}\left(\mu \mathrm{mol}^{-1} \mathrm{l}^{-1}\right)$ & & \\
1000 & $0.97 \pm 0.05^{\mathrm{a}}$ & $1.13 \pm 0.07^{\mathrm{b}}$ \\
Probucol $\left(\mu{\left.\mathrm{mol} \bullet 1^{-1}\right)}_{100}\right.$ & $0.74 \pm 0.05^{\mathrm{d}}$ & $2.42 \pm 0.08^{\mathrm{d}}$ \\
10 & $0.82 \pm 0.04^{\mathrm{c}}$ & $2.24 \pm 0.06^{\mathrm{d}}$ \\
1 & $0.92 \pm 0.06$ & $1.44 \pm 0.07$ \\
\hline
\end{tabular}

${ }^{\mathrm{a}} \mathrm{P}<0.05,{ }^{\mathrm{b}} \mathrm{P}<0.01$ compared with control; ${ }^{\mathrm{C}} \mathrm{P}<0.05,{ }^{\mathrm{d}} \mathrm{P}<0.01$ compared with $\mathrm{H}_{2} \mathrm{O}_{2}$ group. $\mathrm{H}_{2} \mathrm{O}_{2}$, hydrogen peroxide; VSMCs, vascular smooth muscle cells.

through different signal transduction pathways (15,17-19). Therefore, the redox state of equilibrium formed by the molecular oxidation and reduction reactions will have a decisive role in VSMC proliferation or apoptosis, and thus affect vascular disease development and prognosis. The intracellular thioredoxin and glutathione (GSH) systems constitute the most two important reduction systems. The thioredoxin system consists of NADPH, thioredoxin reductase (TrxR) and $\operatorname{Trx}$. Trx-1 is located in the cytoplasm, which is characterized by the surface of the protein molecules having a Trp-Cys-Gly-Pro-Cys-Lys structure, two of which may be oxidized to form a Cys reversible disulfide bridge, and re-reducted by the TrxR with NADPH participation. Trx activity was capable of reducing the SS bridge exposed on the transcription factor surface and keeping the reduction state and restoring the transcription factor activity. Trx-1 has anti-apoptotic activity. ASK-1 is activated by cytokines and stress stimuli factors. By activating c-Jun NH2-terminal kinase (JNK) and p38MAPK, cell apoptosis is induced $(13,20,21)$. Trx-1 is the main regulatory factor of ASK-1 that functions through the oxidation of the Trx active site Trp-Cys-Gly-Pro-Cys-Lys structure. ROS cause the two cysteines to form intramolecular disulfide bonds, form the
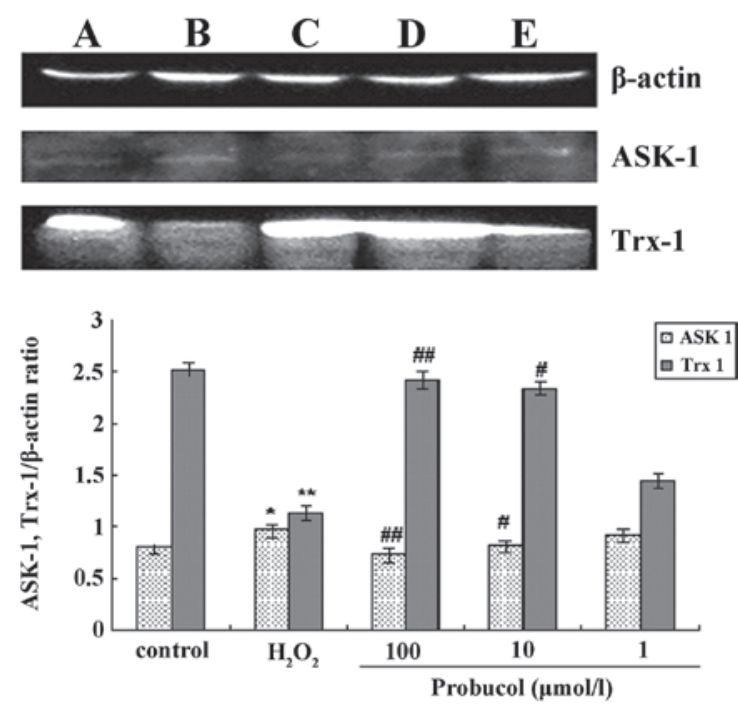

Figure 5. Effects of different concentrations of probucol on the expression of ASK-1 and Trx-1 in VSMC-stimulated by $\mathrm{H}_{2} \mathrm{O}_{2}$. Cells were exposed to $1000 \mu \mathrm{mol} \cdot 1^{-1} \mathrm{H}_{2} \mathrm{O}_{2}$ and different concentrations of 100,10 and $1 \mu \mathrm{mol} / 1 \mathrm{of}$ probucol for $6 \mathrm{~h}$. Activity of Trx-1 and ASK-1 in the medium was evaluated by SDS-PAGE assay. The expression of Trx-1 and ASK-1 were demonstrated as stained bands. (A) Control; (B) $1000 \mu \mathrm{mol} \cdot \cdot^{-1} \mathrm{H}_{2} \mathrm{O}_{2}$; (C) $100 \mu \mathrm{mol} \cdot{ }^{-1}$; (D) $10 \mu \mathrm{mol} \cdot 1^{-1}$; and (E) $1 \mu \mathrm{mol} \cdot 1^{-1}$ of probucol, respectively. Staining regions of the bands were quantified by densitometry. The expression of Trx-1 was increased $(\mathrm{n}=4) .{ }^{*} \mathrm{P}<0.05 ;{ }^{* *} \mathrm{P}<0.01$ compared with control; ${ }^{\#} \mathrm{P}<0.05 ;{ }^{\# \#} \mathrm{P}<0.01$ compared with the $\mathrm{H}_{2} \mathrm{O}_{2}$ group.

oxidized Trx, separate Trx and ASK-1, and free ASK-1 induces apoptosis through the JNK/p38MAPK pathway $(21,22)$.

$\mathrm{H}_{2} \mathrm{O}_{2}$ is one of the most important ROS signal transduction molecules. It can induce apoptosis of many types of cells, and can also be used as an extracellular second messenger of stimulating factors involved in the process of intracellular signal transduction that induce apoptosis $(20,23) . \mathrm{H}_{2} \mathrm{O}_{2}$ may induce apoptosis through a number of different signaling pathways. $\mathrm{H}_{2} \mathrm{O}_{2}$ is capable of enhancing mitogen-activated protein kinases (MAPKs), mainly through c-Jun N-terminal kinase (JNK) and p38 MAPK. However, the non-extracellular signalregulated protein kinase (ERK) pathway induced VMSC apoptosis (24). $\mathrm{H}_{2} \mathrm{O}_{2}$ is capable of activating the mitochondrial fusion protein 2 (Mitofusin 2, Mfn-2), which can reduce the phosphorylation of Akt and inhibit its anti-apoptotic activity, and increase the mitochondrial $\mathrm{Bax} / \mathrm{Bcl}-2$ ratio, cytochrome $\mathrm{C}$ release, and activation of caspases- 9 and caspase- 3 signaling pathway-induced VSMC apoptosis (25). ASK-1 is a mitogenactivated protein kinase kinase family member. ASK1 activity depends on the interaction of the N-terminal homology (N-terminal homophilic interaction). Studies have shown that after a reduction in Trx, tumor necrosis factor receptorassociated factor (TRAF) combining with ASK-1, the ASK-1 $\mathrm{N}$-terminal coiled-coil domain could adjust its N-terminal homology interactions (N-terminal homophilic interaction) and thereby affect ASK-1 function (26). By inhibiting the interaction of the N-terminal homology functional activity, Trx inhibits ASK-1, while $\mathrm{H}_{2} \mathrm{O}_{2}$, TRAF2 and TRAF6 enhanced ASK-1 activity through interactions between the $\mathrm{N}$-terminal homology. However, at present, $\mathrm{H}_{2} \mathrm{O}_{2}$-induced VSMC apoptosis and the reports on the correlation of Trx-1 with ASK-1 have remained relatively limited. 
Probucol is a chain breaking antioxidant; its structure consists of two butyl-hydroxy toluene parts, and it can be used as a single electron donor and singlet oxygen scavenger to remove oxygen free radicals within cells. In addition, probucol can decrease oxidative lipid and cholesterol levels, and reduce the lipid necrotic core area, causing AS plaque stabilization and anti-restenosis $(6-8,27)$. Probucal is recognized to have antioxidant mechanisms, and acts on ox-LDL and against ischemia-reperfusion injury-induced apoptosis $(28,29)$. The method by which probucol inhibits apoptosis signal regulating mechanisms has not yet been fully understood. Recent studies have shown that probucol significantly reduced p53, Bax and caspase- 3 mRNA expression, and enhanced $\mathrm{Bcl} 2$ mRNA expression and resistance to apoptosis $(30,31)$. However, whether the effect of probucol against VSMC apoptosis is related to ASK-1 and Trx-1 has not been reported. This study shows that different concentrations of $\mathrm{H}_{2} \mathrm{O}_{2}$ are capable of inducing VSMC apoptosis in a dose-dependent manner. High concentrations $(1000 \mu \mathrm{mol} / \mathrm{l})$ of $\mathrm{H}_{2} \mathrm{O}_{2}$ led to a large amount of VSMC apoptosis (apoptotic rate of 29.57\%). Probucol could cause significant resistance to $\mathrm{H}_{2} \mathrm{O}_{2}$-induced VSMC apoptosis in a dose-dependent manner; $100 \mu \mathrm{mol} / 1$ probucol is capable of reducing the $\mathrm{H}_{2} \mathrm{O}_{2}$-induced VSMC apoptosis to significantly near to the control group level $(1.46 \pm 0.82$ vs. $3.50 \pm 1.54)$. Probucol increased Trx-1 expression that was significantly downregulated by the $\mathrm{H}_{2} \mathrm{O}_{2}$, while ASK-1 expression was significantly reduced in a dose-dependent manner. Thus, probucol inhibition of ROS-induced apoptosis of VSMCs may be related to ASK-1 and Trx-1, indicating that increased Trx-1 levels and increased levels of Trx-1-ASK-1 complexes may be the mechanism of probucol inhibition of ROS-induced apoptosis of VSMCs, but the detailed mechanism remains to be studied.

\section{References}

1. Liu N and Liu JT: Anoikis in rapture of atherosclerotic plaque. Chin Pharmacol Bull 23: 298-301, 2007.

2. Clarke MC, Littlewood TD, Figg N, et al: Chronic apoptosis of vascular smooth muscle cells accelerates atherosclerosis and promotes calcification and medial degeneration. Circ Res 102: 1529-1538, 2008.

3. Rudijanto A: The role of vascular smooth muscle cells on the pathogenesis of atherosclerosis. Acta Med Indones 39: 86-93, 2007.

4. Boyle JJ: Macrophage activation in atherosclerosis: pathogenesis and pharmacology of plaque rupture. Curr Vasc Pharmacol 3: 63-68, 2005.

5. Stoneman VE and Bennelt MR: Role of apoptosis in atherescleresis and its therapeutic implications. Clin Sci (Lond) 107: 343-354, 2004

6. Ko YG, Kim BK, Lee BK, et al: Study design and rationale of "Synergistic effect of combination therapy with cilostazol and ProbUcol on plaque stabilization and lesion REgression (SECURE)" study: a double-blind randomised controlled multicenter clinical trial. Trials 12: 10, 2011.

7. Kaminnyi AI, Lankin VZ, Samko AN, et al: Low daily dose of antioxidant probucol decreases incidence and severity of restenosis after transluminal coronary balloon angioplasty. Bull Exp Biol Med 139: 183-185, 2005.

8. Wu BJ, Kathir K, Witting PK, et al: Antioxidants protect from atherosclerosis by a heme oxygenase-1 pathway that is independent of free radical scavenging. J Exp Med 203: 1117-1127, 2006.

9. Kyaw M, Yoshizumi M, Tsuchiya K, et al: Atheroprotective effects of antioxidants through inhibition of mitogen-activated protein kinases. Acta Pharmacol Sin 25: 977-985, 2004.
10. Choy K, Beck K, Png FY, et al: Processes involved in the sitespecific effect of probucol on atherosclerosis in apolipoprotein E gene knockout mice. Arterioscler Thromb Vasc Biol 25: 1684-1690, 2005.

11. Sheng L, Pan QX, Liu YJ, et al: Prevention of probucol against $\mathrm{H}_{2} \mathrm{O}_{2}$ induced apoptosis in rat vascular smooth muscle cells. Acts Acad Med Shandong 39: 370-372, 2001.

12. Irani K: Oxidant signaling in vascular cell growth, death and survival. Circ Res 87: 179-187, 2000.

13. Yamawaki H, Haendeler J and Berk BC: Thioredoxin: A Key Regulator of Cardiovascular Homeostasis. Circ Res 93: 1029-1033, 2003.

14. Hsieh CC, Yen MH, Yen CH and Lau YT: Oxidized low density lipoprotein induces apoptosis via generation of reactive oxygen species in vascular smooth muscle cells. Cardiovasc Res 49: 135-145, 2001.

15. Schauer IE, Knaub LA, Lloyd M, et al: CREB downregulation in vascular disease: a common response to cardiovascular risk. Arterioscler Thromb Vasc Biol 30: 733-741, 2010.

16. Sharpe PC, Yue KK, Catherwood MA, McMaster D and Trimble ER: The effects of glucose-induced oxidative stress on growth and extracellular matrix gene expression of vascular smooth muscle cells. Diabetologia 41: 1210-1219, 1998.

17. Satoh K, Nigro P and Berk BC: Oxidative stress and vascular smooth muscle cell growth: a mechanistic linkage by cyclophilin A. Antioxid Redox Signal 12: 675-682, 2010.

18. Touyz RM: Reactive oxygen species and angiotensin II signaling in vascular cells -- implications in cardiovascular disease. Braz J Med Biol Res 37: 1263-1273, 2004.

19. Paravicini TM and Touyz RM: Redox signaling in hypertension. Cardiovasc Res 71: 247-258, 2006.

20. Takeda K, Matsuzawa A, Nishitoh H and Ichijo H: Roles of MAPKKK ASK1 in stress-induced cell death. Cell Struct Funct 28: 23-29, 2003.

21. Song JJ and Lee YJ: Differential role of glutaredoxin and thioredoxin in metabolic oxidative stress-induced activation of apoptosis signal-regulating kinase1. Biochem J 373: 845-853, 2003.

22. Watson WH, Yang X, Choi YE, Jones DP and Kehrer JP: Thioredoxin and its role in toxicology. Toxicol Sci 78: 3-14, 2004.

23. Qian ZQ, Zeng YY, Wang T, et al: VEGF induces HUVECs to produce extracellular $\mathrm{H}_{2} \mathrm{O}_{2}$ and its proliferation role. Chin $\mathrm{J}$ Pathophysiology 23: 533-535, 2007.

24. Tsujimoto A, Takemura G, Mikami A, et al: A therapeutic dose of the lipophilic statin pitavastatin enhances oxidant-induced apoptosis in human vascular smooth muscle cells. J Cardiovasc Pharmacol 48: 160-165, 2006.

25. Guo X, Chen KH, Guo Y, et al: Mitofusin 2 triggers vascular smooth muscle cell apoptosis via mitochondrial death pathway. Circ Res 101: 1113-1122, 2007.

26. Fujino G, Noguchi T, Matsuzawa A, et al: Thioredoxin and TRAF family proteins regulate reactive oxygen species-dependent activation of ASK1 through reciprocal modulation of the N-terminal homophilic interaction of ASK1. Mol Cell Biol 27: 8152-8163, 2007.

27. Yang YB, Liao DF, Xie ZZ and Huang HL: Probucol prevention against restenosis by regulating functional vascular remodeling after percutaneous transluminal angioplasty in rabbits. Chin Pharmacol Bull 19: 388-392, 2003.

28. Su B, He H, Luo QF, Zu BY and Liao DF: Effects of probucol on ox-LDL induced apoptosis and CD36, Caveolin-1 expression in THP-1 macrophages. Chin Pharmacol Bull 23: 1167-1171, 2007.

29. Ruixing Y, Al-Ghazali R, Wenwu L and Jinzhen W: Pretreatment with probucol attenuates cardiomyocyte apoptosis in a rabbit model of ischemia/reperfusion. Scand J Clin Lab Invest 66: 549-558, 2006.

30. Asiri YA: Probucol attenuates cyclophosphamide-induced oxidative apoptosis, p53 and Bax signal expression in rat cardiac tissues. Oxid Med Cell Longev 3: 308-316, 2010.

31. Tang X, Yang X, Peng Y and Lin J : Protective effects of lycopene against $\mathrm{H}_{2} \mathrm{O}_{2}$-induced oxidative injury and apoptosis in human endothelial cells. Cardiovasc Drugs Ther 23: 439-448, 2009. 